\title{
A LOCAL CORN SHELLER PERFORMANCE AS AFFECTED BY MOISTURE CONTENT AND MACHINE ROTATIONAL SPEED
}

\author{
Hany M. El Sharawy*, Adel H. Bahnasawy **, \\ Zakaria A. EL Haddad $* * *$ and Mohamed T. Afifi****
}

\begin{abstract}
A local corn sheller was evaluated at different rotational speeds of (40, 60, 80, 100 and 120 rpm) and moisture contents of (12, 16 and 20\%). The performance was evaluated in terms of sheller productivity, shelling efficiency, unshelled grains, grain damage, loose grains at kernel outlet, specific energy consumption and operational cost. Sheller productivity, shelling efficiency, and the percentage of unshelled grains ranged from 0.43 to 1.46 ton $/$ h, from 94.25 to $99.43 \%$, and from 0.57 to $5.75 \%$, respectively. The percentage of grain damage and loose grains at kernel outlet ranged from 0.21 to $2.13 \%$, from 1.57 to $25.15 \%$, respectively. Meanwhile, specific energy consumption and operational cost ranged from 0.74 to $6.87 \mathrm{~kW} . \mathrm{h} /$ ton and from 18.19 to $64.42 \mathrm{LE} /$ ton, respectively. It was found that increasing the speed caused an increase in performance of shelling and the percentage of broken grains. It is concluded that corn having $12 \%$ moisture content that fed to the sheller at rotational speed of 120 rpm gave the best performance of shelling.
\end{abstract}

Keywords: Maize sheller, Shelling efficiency, Productivity, Specific energy consumption.

\section{INTRODUCTION}

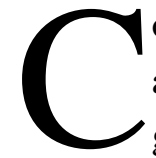
orn is one of the most important cereal crops in the world after wheat and rice. It is called as queen of cereals and king of fodder due to its great importance in human and animal diet. Maize is an important source of carbohydrate, protein, iron, vitamin B and minerals. It is used in human feeding, industrial aspects for producing, corn oil, starch, syrup, alcohol, acids, and dry food for animal.

\footnotetext{
* Graduate Student of Agric. Eng. Dep., Fac. of Agric., Benha Univ., Egypt

** Professor. of Agric. Eng., Fac. of Agric., Benha Univ., Egypt

*** Professor Emeritus. of Agric. Eng., Fac. of Agric., Benha Univ., Egypt

*** Lecturer. of Agric. Eng., Fac. of Agric., Benha Univ., Egypt
} 
The global world production of Maize exceeded 1037.79 million ton per year. It is also considered one of the most important grain crops in Egypt. The cultivated area of corn in Egypt is around 1.039 million hectares with total productivity of about 8.06 million ton (FAO, 2014).

The sequence of maize processing includes, harvesting, de-husking, shelling, winnowing, drying, bagging, and storage (Buliaminu, 2011). Maize shelling or simply maize threshing is the most important aspect of post-harvest operation of maize. Threshing or shelling is one of the most important crop processing operations to separate the grains from ear heads or the plants and prepare it for market. Traditionally, dehusking and shelling of maize are carried out manually which involves a lot of drudgery. The grains were detached from dried dehusked cobs by manual or mechanical device, which is known as shelling. They added that this operation is highly labour intensive and more drudgery in addition to losses of grain in terms of quantity and quality (Chilur et al., 2014).

Maize shelling is defined as removal of grains from the cobs by the initial impact, and rubbing action as the material passes through a restricted clearance between the cylinder, and concave bars (Ayetigbo, 2001). This design works on the principle of abrasion; an application of force tangentially on a surface. the beater discs pull and shell the maize cobs by friction and shearing action against the spiked cast iron projections on either side of the thresher bar. The empty cobs will pass out through the cobs outlet opening and are thrown out by the force of rotation of the shelling discs, and then grain will spread through the grain outlet (collector and port) (Wanjala, 2014).

Naveenkumar and Rajshekarappa (2012) reported that the capacity of sheller was found significantly different for each sheller arrangement and speed combination at moisture contents. Higher capacity of shelling $(402.01 \mathrm{~kg} / \mathrm{h})$ was found when maize having 13 per cent moisture fed to sheller having cylinder rotating at a speed of $350 \mathrm{rpm}$. This was because the time of shelling was minimum compared to other treatment combinations. Energy per unit mass of the shelled corn decreased with the increase in both shelling speed and feeding rate (Al Jalil and Chowdury, 1980). 
The relationship between power consumed and grain moisture content for the motorized sheller, indicating that decreasing the grain moisture content from 14 to $10 \%$, the power decreased from 30 to 12 Watt $(0.040$ to $0.016 \mathrm{hp}$ ), respectively. This may be due to the decrease in adhesion force between grains and corn cob (Arif, 2003). The cost of power operated shelling was less compared to processing with other traditional shelling methods (Naveenkumar and Rajshekarappa, 2012).

The cost of shelling one ton of corn grain was estimated to be $33.33 \mathrm{LE}$ and 89.5 LE for the motorized and manually operated shellers, respectively, while the cost of shelling one ton manually was $142 \mathrm{LE}$ (Aref, 2003). Manual shelling of maize is a time-consuming and tedious operation. Most of corn shellers available now in the market are Chinese made. Tanta Motors Company produces large capacity corn shellers which are not suitable for small farmers. However, in our department there is a locally fabricated small corn sheller which is used by small farmers. The main aim of this work is to evaluate the performance of this machine.

\section{MATERIALS AND METHODS}

The experiments were conducted at Agricultural Engineering Department, Agriculture College, Moshtohor, Benha University, during the period of 2015-2016 to evaluate a local maize sheller.

\subsection{Materials:}

\subsubsection{Crop:}

One variety of corn was used to be shelled in this investigation which known as hytech, 2031(W) single hybrid.

\subsubsection{The corn sheller:}

The corn sheller, which consists mainly of frame, feeding hopper, shelling device, outlets, Motor, and transmission system, is shown in fig. (1). The hopper was fabricated in trapezoidal shape, using wood of 18.62 $\mathrm{mm}$ thickness and dimensions of $70 \mathrm{~cm}$ length, $37.5 \mathrm{~cm}$ width and $20 \mathrm{~cm}$ height. Inclination angle of the hopper $7^{\circ}$. The shelling device consists of spiked tooth disc, concave, threshing bar, and rasped thresher disc.

The disc dimensions are $40 \mathrm{~mm}$ diameter, $12.68 \mathrm{~mm}$ thickness, $7.11 \mathrm{~mm}$, length and $12.06 \mathrm{~mm}$ thickness of each teeth and $7.75 \mathrm{~mm}$ the distance 
between two teeth in the vicinity. The concave is made of galvanized iron sheet. The concave dimensions are $30 \mathrm{~cm}$ diameter, $40 \mathrm{~cm}$ length, 6.51 $\mathrm{mm}$ thickness, $4 \mathrm{~cm}$ hole length and $8.24 \mathrm{~mm}$ hole width. The clearance between the concave and the spike tooth disc was $6 \mathrm{~cm}, 1 \mathrm{~cm}$ from the top and the bottom respectively.
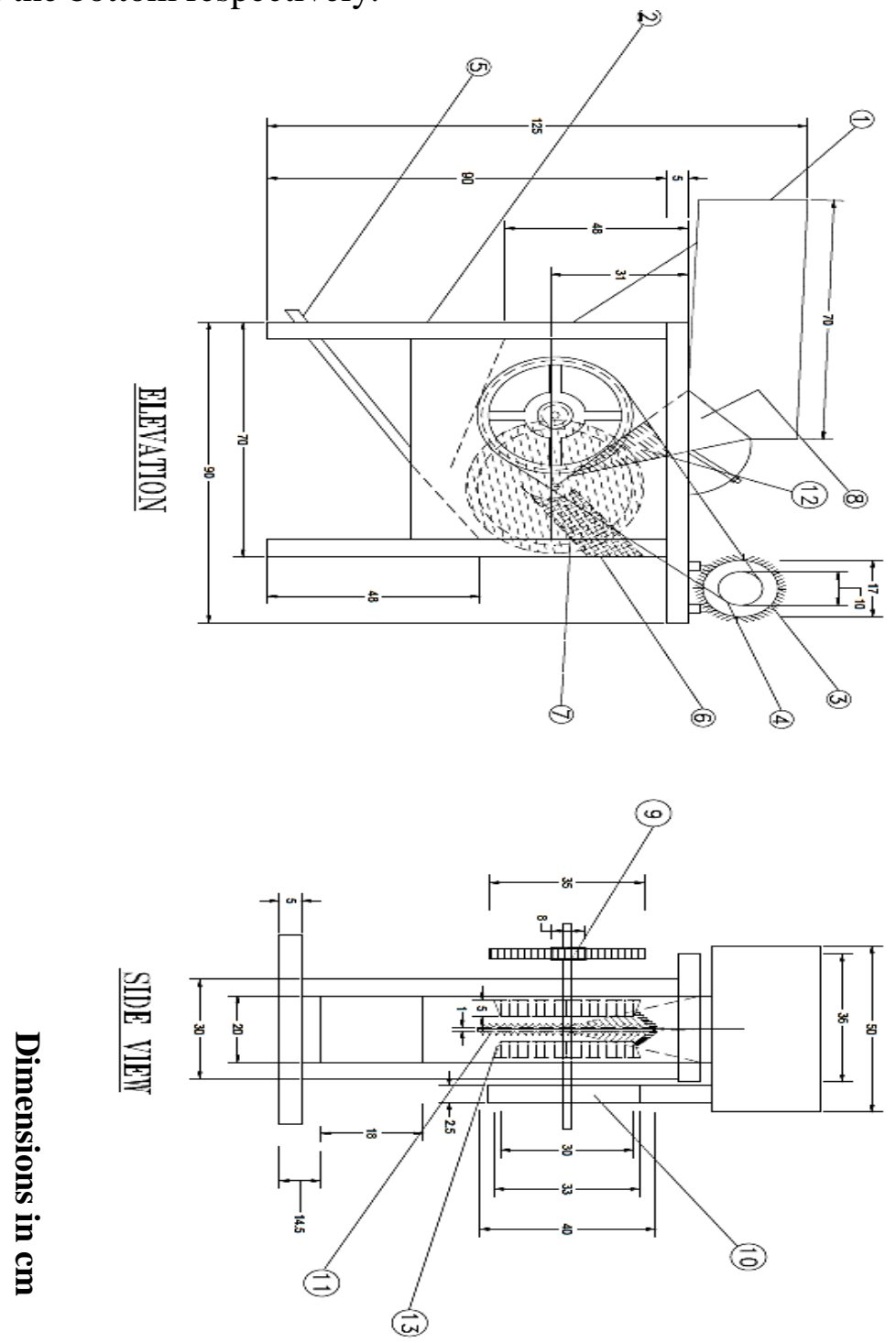

(1) Hopper, (2) Frame, (3) Motor, (4) Motor pulley, (5) Grain outlet, (6) Kernel outlet, (7) Concave, (8) Cob guide, (9) Toothed Gearing system, (10) Sheller pulley, (11) Spike tooth disk, (12) Threshing bar, and (13) rasped thresher disk

\section{Fig.1. Views of the corn sheller}


The threshing bar dimensions are $12 \mathrm{~cm}$ length, $6 \mathrm{~cm}$ width and $20 \mathrm{~mm}$ thickness. The rasped thresher disc dimensions are $30 \mathrm{~cm}$ diameter, 64.97 $\mathrm{mm}$ thickness, $10.94 \mathrm{~mm}$ thickness of each rasp and $10 \mathrm{~mm}$ the distance between two rasps on the disc. The machine has two outlets; the outlet for separated grains was made at the bottom of the shelling disc. It was made up of metal sheet to collect grains without shattering outside and its specifications were $18 \times 20 \mathrm{~cm}$. The empty cobs will pass out through the cobs outlet opening which made along shelling disc and are thrown out by the force of rotation of the shelling disc.

The kernel outlet shape was half of circle $15 \mathrm{~cm}$ diameter. The machine is to be operated by electric motor $(1.5 \mathrm{hp})$. Motion of the motor provides an angular velocity that is translated to the pulley. The driven pulley is fixed on the primary shaft hence the resultant velocity of the driven pulley generates power on this shaft hence providing rotary motion of the rasp thresher discs which pull the cobs. This total power is transmitted to the secondary shaft via toothed gearing mechanism hence providing rotary motion of the spike tooth disc which shells the maize cobs by friction and shearing action against the spiked cast iron projections on either side of the spike tooth disc. The overall dimensions of the corn sheller are $125 \mathrm{~cm}$ height, $50 \mathrm{~cm}$ width, and $135 \mathrm{~cm}$ length.

\subsubsection{Measuring devices:}

2.1.3.1. Vernier caliper (model DIN 862, measuring range $0-150 \mathrm{~mm}$ with an accuracy of $\pm 0.05 \mathrm{~mm}$ ) and steel measuring tape (made in China, measuring range $0-3 \mathrm{~m} / 10 \mathrm{ft}$ with an accuracy of $\pm 1 \mathrm{~mm}$ ) were used to measure dimensions of the corn sheller and corn grains.

2.1.3.2. The power requirement $(\mathrm{kW})$ was determined by recording the voltage and current strength by using the clamp meter (made in China, Model DT266, measuring range 200/1000A and 750/1000V with an accuracy of \pm 0.01 ) to measure the line current strength (I) and the potential difference value $(\mathrm{V})$.

2.1.3.3. Two digital balances were used during the experiment execution. Balance (1) (made in China, Model YH-T7E, measuring range of 0-300 $\mathrm{kg} \pm 0.05 \mathrm{~kg}$ ). It was used to determine the mass of the corn cobs before shelling process. Balance (2) (made in Japan, model CG-12K, measuring 
range of $0-12 \mathrm{~kg} \pm 0.001 \mathrm{~kg}$ ). It was used to determine the mass of the grains and kernel samples after shelling process.

2.1.3.4. Grain moisture tester (made in Japan, model PM 300 and accuracy $\pm 0.2-0.5 \%$ ) It is used to record moisture content for corn grains.

2.1.3.5. A digital tachometer (contact/photo) (made in Japan, model 461895 and accuracy $\pm 0.05 \%$ ) was used to measure the rotational shaft speeds of the corn sheller.

2.1.3.6. Inverter (made in Korea, model SV004iC5-1f); The LS Industrial Systems iC5 adopts a sensorless vector control algorithm, which improves not only the torque control characteristics, but also the speed controllability in certain conditions caused by load variation. It was used with power range of $(0.5-3 \mathrm{hp})$.

\subsection{Methods:}

Sheller productivity, shelling efficiency, cleaning efficiency, grain losses, grain damage, power requirements and costs were determined as follows:

\subsubsection{Sheller productivity:}

At each treatment, shelled grains weight and the shelling time (T) in seconds were recorded, then the machine productivity $(\mathrm{Mp})$, ton/h was calculated as follows:

$$
M_{p}=\frac{M_{t} \times 3600}{T \times 1000}
$$

Where:

$$
\begin{aligned}
& \mathrm{M}_{\mathrm{t}}=\text { Mass of total grains in the sample, } \mathrm{kg} . \\
& \mathrm{T}=\text { Shelling time, sec. }
\end{aligned}
$$

\subsubsection{Shelling efficiency:}

The shelling efficiency was calculated from the following relation:

$$
\begin{aligned}
& \qquad \boldsymbol{E}_{\boldsymbol{s h}}=\frac{\boldsymbol{M}_{\boldsymbol{t}}-\boldsymbol{M}_{\boldsymbol{u}}}{\boldsymbol{M}_{\boldsymbol{t}}} \\
& \mathrm{E}_{\mathrm{sh}}=\text { shelling efficiency, } \% \text {. } \\
& \mathrm{M}_{\mathrm{un}}=\text { mass of unshelled grains, } \mathrm{kg} \text {. }
\end{aligned}
$$

\subsubsection{Grain losses:}

The grain losses values were classified into unshelled grains and loose grains at kernel outlet: 


\subsubsection{Unshelled grains percentage:}

After shelling operation, the unshelled grains from the cobs were shelled manually and weighted then unshelled grains percentage was calculated as follows:

$$
\text { LosS }_{\text {unshelled }}=\frac{M_{u n}}{M_{t}} \times 100
$$

Where:

$$
\text { Loss }_{\text {unshelled }}=\text { losses of unshelled grains, } \% \text {. }
$$

\subsubsection{Loose grains at kernel outlet:}

The loose grains which found with the residual of cobs (kernel) were weighted and then its percentage was calculated as follows:

$$
\text { Loss }_{\text {kernels outlet }}=\frac{M_{k}}{M_{t}} \times 100
$$

Where:

Loss kernels outlet $=$ Loose grains at kernel outlet, $\%$.

$\mathrm{M}_{\mathrm{k}}=$ mass of grains with kernels, $\mathrm{kg}$.

\subsubsection{Grain damage:}

The mass the split and cracked grains were weighted to determine the percentage of grain damage as follow:

$$
\text { Grain damage }=\frac{\text { mass of } \text { split grains }}{\text { total weight of grains }} \times 100
$$

\subsubsection{Power consumption and energy requirements:}

\subsubsection{Electrical power}

Electrical power consumption was estimated from the measured electric current and voltage values and estimated according to Kurt (1979) as follows from equation:

$$
E p=\frac{\sqrt{3} * I * V * \eta * \cos \varphi}{1000}
$$

Where:

Ep: electrical power, kW; I: electric current, Amperes.

$\eta$ : Mechanical efficiency assumed to be 0.95 (Metwally,2010).

$\mathrm{V}$ : electrical voltage, $\mathrm{V}$.

$\cos \varphi$ : Power factors being equal to (0.84).

\subsubsection{Human power:}

According to Odigboh (1997), at the maximum continuous energy consumption rate of $0.30 \mathrm{~kW}$ and conversion efficiency of $25 \%$, the physical power output of a normal human labor in tropical climates is 
approximately $0.075 \mathrm{~kW}$ sustained for an $8-10 \mathrm{~h}$ workday. This was calculated mathematically as:

$$
E m=0.075 \mathrm{~N}
$$

Where: Em: Human power, $\mathrm{kW}$.

$\mathrm{N}$ : The number of persons involved in an operation.

The total power consumed is the summation of the electrical power and human power.

\subsubsection{Specific energy consumption:}

The specific energy consumption (SEC) was calculated by using the following equation:

$$
S E C=\frac{\text { Total power consumption }}{\text { Productivity }}, \mathrm{kW} . \mathrm{h} / \mathrm{ton}
$$

\subsubsection{Shelling cost:}

Hourly cost is calculated according to the equation that is given by Awady (1978) as follows.

$$
C=\frac{p}{h}\left(\frac{1}{a}+\frac{i}{2}+t+r\right)+(E c * E p)+\frac{m}{240}
$$

Where:

C: hourly cost, LE/h.

p: price of the equipment, LE.

$\mathrm{h}$ : year by working hours.

$\mathrm{h}$; a: life expected of the machine, year.

i: Interest rate, $\%$.

t: taxes and overheads ratio, $\%$.

r: repair and maintenance ratio, $\%$.

Ec: power of motor, $\mathrm{kW}$.

Ep: electricity cost, LE/kW. h.

m: operator monthly salary, LE.

240: the monthly average working hours.

\begin{tabular}{|c|c|c|c|c|c|c|c|c|}
\hline $\begin{array}{c}\mathrm{P}, \\
\mathrm{LE}\end{array}$ & $\mathrm{h}$ & $\begin{array}{c}\mathrm{a}, \\
\text { year }\end{array}$ & $\mathrm{i}, \%$ & $\mathrm{t}, \%$ & $\mathrm{r}, \%$ & $\begin{array}{c}\mathrm{Ec}, \\
\mathrm{kW} . \mathrm{h} / \mathrm{h}\end{array}$ & $\begin{array}{c}\mathrm{Ep}, \\
\text { L.E }\end{array}$ & $\begin{array}{c}\mathrm{m}, \\
\text { L.E }\end{array}$ \\
\hline 4000 & 1000 & 10 & 10 & 5 & 3 & $0.77-2.63$ & 0.63 & 1500 \\
\hline
\end{tabular}

\section{RESULTS AND DISCUSSIONS}

Corn sheller was evaluated by studying the effect of the rotational speed and corn moisture content on the productivity, shelling efficiency, unshelled grains, grain damage, loose grains at kernel outlet, shelling 
time, power and specific energy requirements. Costs were also determined at the previous treatments.

\subsection{Sheller productivity:}

Table 1. shows the effect of rotational speed and grains moisture content on the productivity of the corn sheller. It could be seen that the productivity of the corn sheller decreased with increasing the moisture content and increased by increasing rotational speed, where it increased from 0.79 to $1.46 \mathrm{ton} / \mathrm{h}$ at $12 \%$ moisture content, from 0.66 to $1.00 \mathrm{ton} / \mathrm{h}$ at $16 \%$ moisture content and it increased from 0.43 to 0.93 ton/h at $20 \%$ corn grains moisture content when the rotational speed increased from 40- $120 \mathrm{rpm}$.

Table 1. Effect of rotational speed and grains moisture content on the sheller productivity.

\begin{tabular}{|c|c|c|c|c|c|c|c|}
\hline \multirow{3}{*}{$\begin{array}{l}\text { Moisture } \\
\text { content, \% }\end{array}$} & \multicolumn{5}{|c|}{ Rotational speed, rpm } & \multirow{3}{*}{$\begin{array}{l}\text { Mean of } \\
\text { moisture } \\
\text { content }\end{array}$} & \multirow{3}{*}{$\begin{array}{c}\text { Manual } \\
\text { shelling, } \\
\text { kg/h }\end{array}$} \\
\hline & 40 & 60 & 80 & 100 & 120 & & \\
\hline & \multicolumn{5}{|c|}{ Sheller productivity, ton/h } & & \\
\hline 12 & $0.79^{\mathrm{e}}$ & $0.92^{d}$ & $1.07^{\mathrm{c}}$ & $1.18^{\mathrm{b}}$ & $1.46^{\mathrm{a}}$ & $1.08^{\mathrm{a}}$ & 48 \\
\hline 16 & $0.66^{\mathrm{f}}$ & $0.75^{\mathrm{e}}$ & $0.91^{\mathrm{d}}$ & $0.98^{\text {cd }}$ & $1.00^{\mathrm{cd}}$ & $0.86^{\mathbf{b}}$ & 36 \\
\hline 20 & $0.43^{\mathrm{h}}$ & $0.54^{\mathrm{g}}$ & $0.65^{\mathrm{f}}$ & $0.76^{\mathrm{e}}$ & $0.93^{d}$ & $0.66^{\mathrm{c}}$ & 21 \\
\hline $\begin{array}{c}\text { Mean of r. } \\
\text { speed }\end{array}$ & $0.63^{\mathrm{e}}$ & $0.74^{d}$ & $0.87^{\mathrm{c}}$ & $0.97^{\mathrm{b}}$ & $1.13^{\mathrm{a}}$ & & \\
\hline \multirow{2}{*}{$\begin{array}{c}\text { LSD at } 0.05 \\
\text { for }\end{array}$} & \multicolumn{2}{|c|}{$\begin{array}{l}\text { Moisture } \\
\text { content }\end{array}$} & \multicolumn{2}{|c|}{$\begin{array}{l}\text { Rotational } \\
\text { speed }\end{array}$} & \multicolumn{2}{|c|}{$\mathrm{MC}^{*} \mathrm{~V}$} & \\
\hline & \multicolumn{2}{|c|}{0.04} & \multicolumn{2}{|c|}{0.05} & \multicolumn{2}{|c|}{0.09} & \\
\hline
\end{tabular}

The reduction percentage was $46.03 \%$ at $40 \mathrm{rpm}$ rotational speed, $40.72 \%$ at $60 \mathrm{rpm}, 39.57 \%$ at $80 \mathrm{rpm}, 35.34 \%$ at $100 \mathrm{rpm}$ and $36.11 \%$ at $120 \mathrm{rpm}$ rotational speed when the grains moisture content increased from 12- 20\%. Meanwhile the increasing percentage due to the effect of rotational speed was $45.76 \%$ at $12 \%$ moisture content, $34.40 \%$ at $16 \%$ moisture content and $54.18 \%$ at $20 \%$ moisture content. It is worthy to mention that the productivity of manual shelling ranged from 21 to 48 $\mathrm{kg} / \mathrm{h}$.

The statistical analysis of the productivity results as affected by rotational speed and grains moisture content showed that there were significant differences between moisture contents. The differences between the sheller productivity due to the effect of rotational speed and moisture 
content were significant. Also the analysis showed that the interaction between moisture content and rotational speed was significant.

Multiple regression was carried out to find a relationship between the sheller productivity and both the moisture content (12- 20\%) and rotational speed $(40-120 \mathrm{rpm})(0.8378-2.5133 \mathrm{~m} / \mathrm{sec})$. the most suitable form obtained was as follows:

$\operatorname{Pr}=1.211-0.053(\mathrm{Mc})+0.006(\mathrm{~V}) \quad \mathrm{R}^{2}=0.958$

Where:

Pr: is the productivity, ton/h.

Mc: is the corn grain moisture content, \% W. b.

$\mathrm{V}$ : is the rotational speed, rpm.

\subsection{Shelling efficiency:}

Table 2. shows the effect of rotational speed and grains moisture content on shelling efficiency. It could be seen that the shelling efficiency decreased with increasing the moisture content and increased by increasing rotational speed, where it increased from 97.34 to $99.43 \%$ at $12 \%$ moisture content, from 96.08 to $99.32 \pm 0.18 \%$ at $16 \%$ moisture content and it increased from 94.25 to 98.14 at $20 \%$ corn grains moisture content when the rotational speed increased from 40-120 rpm.

Table 2. Effect of rotational speed and grains moisture content on shelling efficiency.

\begin{tabular}{|c|c|c|c|c|c|c|}
\hline \multirow{3}{*}{$\begin{array}{c}\text { Moisture } \\
\text { content, \% }\end{array}$} & \multicolumn{5}{|c|}{ Rotational speed, rpm } & \multirow{3}{*}{$\begin{array}{l}\text { Mean of } \\
\text { moisture } \\
\text { content }\end{array}$} \\
\hline & 40 & 60 & 80 & 100 & 120 & \\
\hline & \multicolumn{5}{|c|}{ Shelling efficiency, \% } & \\
\hline 12 & $97.34^{\mathrm{bc}}$ & $98.28^{\mathbf{b}}$ & $98.77^{\mathbf{a b}}$ & $99.35^{\mathrm{a}}$ & $99.43^{\mathrm{a}}$ & $98.63^{\mathrm{a}}$ \\
\hline 16 & $96.08^{\text {cd }}$ & $97.38^{\mathbf{b c}}$ & $98.42^{\mathbf{a b}}$ & $99.00^{\mathbf{a b}}$ & $99.32^{\mathbf{a b}}$ & $98.04^{\mathbf{b}}$ \\
\hline 20 & $94.25^{\mathrm{d}}$ & $95.20^{d}$ & $96.77^{\mathrm{c}}$ & $97.34^{\text {bc }}$ & $98.14^{\mathbf{b}}$ & $96.34^{\mathrm{c}}$ \\
\hline $\begin{array}{l}\text { Mean of } r . \\
\text { speed }\end{array}$ & $95.89^{\mathrm{e}}$ & $96.95^{\mathrm{d}}$ & $97.99^{c}$ & $98.56^{\text {bc }}$ & $98.96^{\mathrm{a}}$ & \\
\hline \multirow{2}{*}{$\begin{array}{c}\text { LSD at } 0.05 \\
\text { for }\end{array}$} & \multicolumn{2}{|c|}{ Moisture content } & \multicolumn{2}{|c|}{ Rotational speed } & \multicolumn{2}{|c|}{$\mathrm{MC} * \mathrm{~V}$} \\
\hline & \multicolumn{2}{|c|}{0.46} & \multicolumn{2}{|c|}{0.60} & \multicolumn{2}{|c|}{1.04} \\
\hline
\end{tabular}

The reduction percentage was $3.17 \%$ at $40 \mathrm{rpm}$ rotational speed, $3.13 \%$ at $60 \mathrm{rpm}, 2.02 \%$ at $80 \mathrm{rpm}, 2.02 \%$ at $100 \mathrm{rpm}$ and $1.30 \%$ at $120 \mathrm{rpm}$ rotational speed when the grains moisture content increased from 12$20 \%$. Meanwhile the increasing percentage due to the effect of rotational 
speed was $2.10 \%$ at $12 \%$ moisture content, $3.26 \%$ at $16 \%$ moisture content and $3.96 \%$ at $20 \%$ moisture content.

The statistical analysis of the percentage of shelling efficiency results as affected by rotational speed and grains moisture content showed that there were significant differences between moisture contents. The differences between the shelling efficiency due to the effect of rotational speed and moisture content were significant. Also the analysis showed that the interaction between moisture content and rotational speed was significant.

Multiple regression was carried out to find a relationship between the shelling efficiency and both the moisture content $(12-20 \%)$ and rotational speed $(40-120 \mathrm{rpm})(0.8378-2.5133 \mathrm{~m} / \mathrm{sec})$. the most suitable form obtained was as follows:

$\eta_{\text {sh }}=99.333-0.287(\mathrm{Mc})+0.035(\mathrm{~V}) \quad \mathrm{R}^{2}=0.905$

Where:

$\eta_{\text {sh }}:$ is the shelling efficiency, $\%$.

\subsection{Unshelled grains:}

Table 3. shows the effect of rotational speed and grains moisture content on unshelled grains. It could be seen that the unshelled grains increased with increasing the moisture content and decreased by increasing rotational speed, where it decreased from 2.66 to $0.57 \%$ at $12 \%$ moisture content, from 3.92 to $0.68 \%$ at $16 \%$ moisture content and it decreased from 5.75 to $1.86 \%$ at $20 \%$ corn grains moisture content when the rotational speed increased from 40-120 rpm.

Table 3. Effect of rotational speed and grains moisture content on unshelled grains.

\begin{tabular}{|c|c|c|c|c|c|c|}
\hline \multirow{3}{*}{$\begin{array}{l}\text { Moisture } \\
\text { content, \% }\end{array}$} & \multicolumn{5}{|c|}{ Rotational speed, rpm } & \multirow{3}{*}{$\begin{array}{l}\text { Mean of } \\
\text { moisture } \\
\text { content }\end{array}$} \\
\hline & 40 & 60 & 80 & 100 & 120 & \\
\hline & \multicolumn{5}{|c|}{ Unshelled grains, $\%$} & \\
\hline 12 & $2.66^{\mathrm{bc}}$ & $1.72^{\mathbf{b}}$ & $1.23^{\mathrm{ab}}$ & $0.65^{\mathrm{a}}$ & $0.57^{\mathrm{a}}$ & $1.37^{\mathrm{a}}$ \\
\hline 16 & $3.92^{\mathrm{cd}}$ & $2.62^{b c}$ & $1.58^{\mathrm{ab}}$ & $1.00^{\mathrm{ab}}$ & $0.68^{\text {ab }}$ & $1.96^{b}$ \\
\hline 20 & $5.75^{\mathrm{d}}$ & $4.80^{\mathrm{d}}$ & $3.23^{\mathrm{c}}$ & $2.66^{\mathrm{bc}}$ & $1.86^{\mathrm{b}}$ & $3.66^{\mathrm{c}}$ \\
\hline Mean of r. speed & $4.11^{\mathrm{d}}$ & $3.05^{\mathrm{c}}$ & $2.01^{\mathbf{b}}$ & $1.44^{\mathrm{ab}}$ & $1.04^{\mathrm{a}}$ & \\
\hline \multirow{2}{*}{$\begin{array}{c}\text { LSD at } 0.05 \\
\text { for }\end{array}$} & \multicolumn{2}{|c|}{ Moisture content } & \multicolumn{2}{|c|}{ Rotational speed } & \multicolumn{2}{|c|}{$\mathrm{MC} * \mathrm{~V}$} \\
\hline & \multicolumn{2}{|c|}{0.46} & \multicolumn{2}{|c|}{0.60} & \multicolumn{2}{|c|}{1.04} \\
\hline
\end{tabular}


The increasing percentage was $53.74 \%$ at $40 \mathrm{rpm}$ rotational speed, $64.17 \%$ at $60 \mathrm{rpm}, 61.92 \%$ at $80 \mathrm{rpm}, 75.56 \%$ at $100 \mathrm{rpm}$ and $69.35 \%$ at $120 \mathrm{rpm}$ rotational speed when the grains moisture content increased from 12-20\%. Meanwhile the reduction percentage due to the effect of rotational speed was $78.57 \%$ at $12 \%$ moisture content, $82.65 \%$ at $16 \%$ moisture content and $67.65 \%$ at $20 \%$ moisture content.

The statistical analysis of the percentage of unshelled grains results as affected by rotational speed and grains moisture content showed that there were significant differences between moisture contents. The differences between the unshelled grains due to the effect of rotational speed and moisture content were significant. Also the analysis showed that the interaction between moisture content and rotational speed was significant.

Multiple regression was carried out to find a relationship between the unshelled grains and both the moisture content $(12-20 \%)$ and rotational speed $(40-120 \mathrm{rpm})(0.8378-2.5133 \mathrm{~m} / \mathrm{sec})$. the most suitable form obtained was as follows:

$\mathrm{Ush}=0.287(\mathrm{Mc})-0.035(\mathrm{~V})+0.667 \quad \mathrm{R} 2=0.905$

Where:

Ush: is the unshelled grains, $\%$.

\subsection{Grain damage:}

Table 4. shows the effect of rotational speed and grains moisture content on grain damage. It could be seen that the Grain damage increased with increasing the moisture content and increased by increasing rotational speed, where it increased from 0.21 to $0.97 \%$ at $12 \%$ moisture content, from 0.67 to $1.53 \%$ at $16 \%$ moisture content and it increased from 0.90 to $2.13 \%$ at $20 \%$ corn grains moisture content when the rotational speed increased from 40-120 rpm.

The reduction percentage was $76.67 \%$ at $40 \mathrm{rpm}$ rotational speed, $74.17 \%$ at $60 \mathrm{rpm}, 74.15 \%$ at $80 \mathrm{rpm}, 62.87 \%$ at $100 \mathrm{rpm}$ and $54.46 \%$ at $120 \mathrm{rpm}$ rotational speed when the grains moisture content increased from 12- 20\%. Meanwhile the increasing percentage due to the effect of rotational speed was $78.35 \%$ at $12 \%$ moisture content, $56.21 \%$ at $16 \%$ moisture content and $57.75 \%$ at $20 \%$ moisture content. 
Table 4. Effect of rotational speed and grains moisture content on grain damage.

\begin{tabular}{|c|c|c|c|c|c|c|}
\hline \multirow{3}{*}{$\begin{array}{c}\text { Moisture } \\
\text { content, \% }\end{array}$} & \multicolumn{5}{|c|}{ Rotational speed, rpm } & \multirow{3}{*}{$\begin{array}{c}\text { Mean of } \\
\text { moisture } \\
\text { content }\end{array}$} \\
\hline & 40 & 60 & 80 & 100 & 120 & \\
\hline & \multicolumn{5}{|c|}{ Grain damage, $\%$} & \\
\hline 12 & $0.21^{\mathrm{a}}$ & $0.31^{\mathrm{a}}$ & $0.38^{\mathbf{a b}}$ & $0.62^{\mathrm{b}}$ & $0.97^{\text {cd }}$ & $0.50^{\mathrm{a}}$ \\
\hline 16 & $0.67^{\text {bc }}$ & $1.03^{\mathrm{cd}}$ & $1.27^{\mathrm{de}}$ & $1.37^{\mathrm{de}}$ & $1.53^{\mathrm{e}}$ & $1.17^{\mathbf{b}}$ \\
\hline 20 & $0.90^{\mathbf{c}}$ & $1.2^{\mathrm{d}}$ & $1.47^{\mathrm{e}}$ & $1.67^{\mathrm{e}}$ & $2.13^{\mathrm{f}}$ & $1.47^{\mathrm{c}}$ \\
\hline Mean of r. speed & $0.59^{\mathrm{a}}$ & $0.85^{\mathbf{b}}$ & $1.04^{\mathrm{c}}$ & $1.22^{\mathrm{d}}$ & $1.55^{\mathrm{e}}$ & \\
\hline \multirow{2}{*}{$\begin{array}{l}\text { LSD at } 0.05 \\
\text { for }\end{array}$} & \multicolumn{2}{|c|}{ Moisture content } & \multicolumn{2}{|c|}{ Rotational speed } & \multicolumn{2}{|c|}{$\mathrm{MC} * \mathrm{~V}$} \\
\hline & \multicolumn{2}{|c|}{0.12} & \multicolumn{2}{|c|}{0.15} & \multicolumn{2}{|c|}{0.26} \\
\hline
\end{tabular}

The statistical analysis of the percentage of grain damage results as affected by rotational speed and grains moisture content showed that there were significant differences between moisture contents. The differences between the grain damage due to the effect of rotational speed and moisture content were significant. Also the analysis showed that the interaction between moisture content and rotational speed was significant.

Multiple regression was carried out to find a relationship between the grain damage and both the moisture content $(12-20 \%)$ and rotational speed $(40-120 \mathrm{rpm})(0.8378-2.5133 \mathrm{~m} / \mathrm{sec})$. the most suitable form obtained was as follows:

$\mathrm{Gd}=0.122(\mathrm{Mc})+0.010(\mathrm{~V})-1.737 \quad \mathrm{R}^{2}=0.914$

Where:

$\mathrm{Gd}$ : is the grain damage, $\%$.

\subsection{Loose grains kernel outlet:}

Table 5. shows the effect of rotational speed and grains moisture content on the loose grains at kernel outlet. It could be seen that the loose grains at kernel outlet decreased with increasing the moisture content and increased by increasing rotational speed, where it increased from 2.44 to $25.15 \%$ at $12 \%$ moisture content, from 2.24 to $22.37 \%$ at $16 \%$ moisture content and it increased from 1.57 to $16.68 \%$ at $20 \%$ corn grains moisture content when the rotational speed increased from 40- $120 \mathrm{rpm}$. 
Table 5. Effect of rotational speed and grains moisture content on the loose grains at kernel outlet.

\begin{tabular}{|c|c|c|c|c|c|c|}
\hline \multirow{3}{*}{$\begin{array}{c}\text { Moisture } \\
\text { content, \% }\end{array}$} & \multicolumn{5}{|c|}{ Rotational speed, rpm } & \multirow{3}{*}{$\begin{array}{c}\text { Mean of } \\
\text { moisture } \\
\text { content }\end{array}$} \\
\hline & 40 & 60 & 80 & 100 & 120 & \\
\hline & \multicolumn{5}{|c|}{ Loose grains at kernel outlet, $\%$} & \\
\hline 12 & $2.44^{\text {ab }}$ & $4.15^{b}$ & $9.89^{d}$ & $16.86^{\mathrm{e}}$ & $25.15^{\mathrm{g}}$ & $11.70^{\mathrm{c}}$ \\
\hline 16 & $2.24^{\mathrm{ab}}$ & $4.10^{\mathrm{b}}$ & $7.72^{\text {cd }}$ & $15.44^{\mathrm{e}}$ & $22.37^{\mathrm{f}}$ & $10.37^{\mathbf{b}}$ \\
\hline 20 & $1.57^{\mathrm{a}}$ & $2.76^{\mathbf{a b}}$ & $6.44^{\mathrm{c}}$ & $9.74^{d}$ & $16.68^{\mathrm{e}}$ & $7.44^{\mathrm{a}}$ \\
\hline Mean of r. speed & $2.08^{\mathrm{a}}$ & $3.67^{b}$ & $8.02^{\mathrm{c}}$ & $14.01^{d}$ & $21.40^{\mathrm{e}}$ & \\
\hline \multirow{2}{*}{$\begin{array}{c}\text { LSD at } 0.05 \\
\text { for }\end{array}$} & \multicolumn{2}{|c|}{ Moisture content } & \multicolumn{2}{|c|}{ Rotational speed } & \multicolumn{2}{|c|}{$\mathrm{MC} * \mathrm{~V}$} \\
\hline & \multicolumn{2}{|c|}{0.95} & \multicolumn{2}{|c|}{1.22} & \multicolumn{2}{|c|}{2.12} \\
\hline
\end{tabular}

The reduction percentage was $35.66 \%$ at $40 \mathrm{rpm}$ rotational speed, $33.49 \%$ at $60 \mathrm{rpm}, 34.88 \%$ at $80 \mathrm{rpm}, 42.23 \%$ at $100 \mathrm{rpm}$ and $33.70 \%$ at $120 \mathrm{rpm}$ rotational speed when the grains moisture content increased from 12- 20\%. Meanwhile the increasing percentage due to the effect of rotational speed was $90.30 \%$ at $12 \%$ moisture content, $89.99 \%$ at $16 \%$ moisture content and $90.59 \%$ at $20 \%$ moisture content.

The statistical analysis of the percentage of loose grains at kernel outlet as affected by rotational speed and grains moisture content showed that there were significant differences between moisture contents. The differences between the loose grains at kernel outlet due to the effect of rotational speed and moisture content were significant. Also the analysis showed that the interaction between moisture content and rotational speed was significant.

Multiple regression was carried out to find a relationship between the loose grains at kernel outlet and both the moisture content (12 - 20\%) and rotational speed $(40-120 \mathrm{rpm})(0.8378-2.5133 \mathrm{~m} / \mathrm{sec})$. the most suitable form obtained was as follows:

$\mathrm{L}=0.245(\mathrm{~V})-0.533(\mathrm{MC})-1.232 \quad \mathrm{R} 2=0.920$

Where:

$\mathrm{L}$ : is the loose grains at kernel outlet, $\%$.

\subsection{Specific energy consumption:}

Table 6. shows the effect of rotational speed and grains moisture content on the specific energy consumption. It could be seen that the specific 
energy consumption increased with increasing the moisture content and decreased by increasing rotational speed, where it decreased from 2.17 to $0.74 \mathrm{~kW}$. h/ton at $12 \%$ moisture content, from 3.08 to $1.43 \mathrm{~kW}$. h/ton at $16 \%$ moisture content and it decreased from 6.87 to $1.61 \mathrm{~kW}$. h/ton at $20 \%$ corn grains moisture content when the rotational speed increased from 40-120 rpm.

Table 6. Effect of rotational speed and grains moisture content on the specific energy consumption.

\begin{tabular}{|c|c|c|c|c|c|c|}
\hline \multirow{3}{*}{$\begin{array}{c}\text { Moisture } \\
\text { content, \% }\end{array}$} & \multicolumn{5}{|c|}{ Rotational speed, rpm } & \multirow{3}{*}{$\begin{array}{l}\text { Mean of } \\
\text { moisture } \\
\text { content }\end{array}$} \\
\hline & 40 & 60 & 80 & 100 & 120 & \\
\hline & \multicolumn{5}{|c|}{ Specific energy consumption, $\mathrm{kW} . \mathrm{h} /$ ton } & \\
\hline 12 & $2.17^{\mathrm{c}}$ & $1.68^{\mathrm{bc}}$ & $1.27^{\mathrm{b}}$ & $1.07^{\mathrm{ab}}$ & $0.74^{\mathrm{a}}$ & $1.38^{\mathrm{a}}$ \\
\hline 16 & $3.08^{\mathrm{d}}$ & $2.46^{\mathrm{c}}$ & $1.71^{\mathrm{bc}}$ & $1.49^{\mathbf{b}}$ & $1.43^{\mathrm{b}}$ & $2.03^{\mathbf{b}}$ \\
\hline 20 & $6.87^{f}$ & $4.40^{\mathbf{e}}$ & $3.19^{d}$ & $2.33^{\mathrm{c}}$ & $1.61^{b}$ & $3.68^{\mathrm{c}}$ \\
\hline Mean of r. speed & $4.04^{\mathrm{e}}$ & $2.85^{d}$ & $2.06^{\mathrm{c}}$ & $1.63^{\mathrm{b}}$ & $1.26^{\mathrm{a}}$ & \\
\hline \multirow{2}{*}{$\begin{array}{l}\text { LSD at } 0.05 \\
\text { for }\end{array}$} & \multicolumn{2}{|c|}{ Moisture content } & \multicolumn{2}{|c|}{ Rotational speed } & \multicolumn{2}{|c|}{$\mathrm{MC} * \mathrm{~V}$} \\
\hline & \multicolumn{2}{|c|}{0.23} & \multicolumn{2}{|c|}{0.29} & \multicolumn{2}{|c|}{0.51} \\
\hline
\end{tabular}

The increasing percentage was $68.41 \%$ at $40 \mathrm{rpm}$ rotational speed, $61.82 \%$ at $60 \mathrm{rpm}, 60.19 \%$ at $80 \mathrm{rpm}, 54.08 \%$ at $100 \mathrm{rpm}$ and $54.04 \%$ at $120 \mathrm{rpm}$ rotational speed when the grains moisture content increased from 12- 20\%. Meanwhile the reduction percentage due to the effect of rotational speed was 65.90 at $12 \%$ moisture content, $53.57 \%$ at $16 \%$ moisture content and $76.56 \%$ at $20 \%$ moisture content.

The statistical analysis of specific energy consumption results as affected by rotational speed and grains moisture content showed that there were significant differences between moisture contents. The differences between the specific energy consumption due to the effect of rotational speed and moisture content were significant. Also the analysis showed that the interaction between moisture content and rotational speed was significant.

Multiple regression was carried out to find a relationship between the specific energy consumption and both the moisture content $(12-20 \%)$ and rotational speed $(40-120 \mathrm{rpm})(0.8378-2.5133 \mathrm{~m} / \mathrm{sec})$. the most suitable form obtained was as follows:

$\mathrm{SEC}=0.287(\mathrm{Mc})-0.034(\mathrm{~V})+0.489 \quad \mathrm{R} 2=0.785$ 
Where:

SEC: is the specific energy consumption, $\mathrm{kW} . \mathrm{h} / \mathrm{ton}$.

\subsection{Cost estimation:}

Table 7. shows the effect of rotational speed and grains moisture content on the operational cost of the corn sheller. It could be seen that the cost of the corn sheller increased with increasing the moisture content and decreased by increasing rotational speed, where it decreased from 33.72 to $18.19 \mathrm{~L} . \mathrm{E} /$ ton at $12 \%$ moisture content, from 41.15 to $26.58 \mathrm{~L} . \mathrm{E} / \mathrm{ton}$ at $16 \%$ moisture content and it decreased from 64.42 to 28.49 L.E/ton at $20 \%$ corn grains moisture content when the rotational speed increased from $40-120 \mathrm{rpm}$.

Table 9. Effect of rotational speed and grains moisture content on the operational cost of the corn sheller.

\begin{tabular}{|c|c|c|c|c|c|c|}
\hline \multirow{3}{*}{$\begin{array}{l}\text { Moisture } \\
\text { content, \% }\end{array}$} & \multicolumn{5}{|c|}{ Rotational speed, rpm } & \multirow{3}{*}{$\begin{array}{l}\text { Mean of } \\
\text { moisture } \\
\text { content }\end{array}$} \\
\hline & 40 & 60 & 80 & 100 & 120 & \\
\hline & \multicolumn{5}{|c|}{ operational cost, L.E/ton } & \\
\hline 12 & $33.72^{d}$ & $29.04^{\mathrm{c}}$ & $24.85^{b c}$ & $22.5^{b}$ & $18.19^{\mathrm{a}}$ & $25.66^{\mathrm{a}}$ \\
\hline 16 & $41.15^{\mathrm{e}}$ & $36.13^{d}$ & $29.49^{c}$ & $27.12^{\mathrm{c}}$ & $26.58^{\mathrm{c}}$ & $32.09^{b}$ \\
\hline 20 & $64.42^{\mathrm{g}}$ & $50.19^{f}$ & $41.98^{\mathrm{e}}$ & $35.20^{\mathrm{d}}$ & $28.49^{\mathrm{c}}$ & $44.06^{\mathrm{c}}$ \\
\hline $\begin{array}{c}\text { Mean of r. } \\
\text { speed }\end{array}$ & $46.43^{\mathrm{e}}$ & $38.45^{\mathrm{d}}$ & $32.11^{\mathrm{c}}$ & $28.27^{\mathbf{b}}$ & $24.42^{\mathrm{a}}$ & \\
\hline \multirow{2}{*}{$\begin{array}{l}\text { LSD at } 0.05 \\
\text { for }\end{array}$} & \multicolumn{2}{|c|}{ Moisture content } & \multicolumn{2}{|c|}{ Rotational speed } & \multicolumn{2}{|c|}{$\mathrm{MC} * \mathrm{~V}$} \\
\hline & \multicolumn{2}{|c|}{1.55} & \multicolumn{2}{|c|}{2.00} & \multicolumn{2}{|c|}{3.47} \\
\hline
\end{tabular}

The increasing percentage was $47.66 \%$ at $40 \mathrm{rpm}$ rotational speed, $42.14 \%$ at $60 \mathrm{rpm}, 40.81 \%$ at $80 \mathrm{rpm}, 36.08 \%$ at $100 \mathrm{rpm}$ and $36.15 \%$ at $120 \mathrm{rpm}$ rotational speed when the grains moisture content increased from 12- 20\%. Meanwhile the reduction percentage due to the effect of rotational speed was $46.06 \%$ at $12 \%$ moisture content, $35.41 \%$ at $16 \%$ moisture content and $55.77 \%$ at $20 \%$ moisture content.

The statistical analysis of the operational cost results as affected by rotational speed and grains moisture content showed that there were significant differences between moisture contents. The differences between the operational costs due to the effect of rotational speed and moisture content were significant. The analysis showed also that the 
interaction between moisture content and rotational speed was significant.

Multiple regression was carried out to find a relationship between the operational cost and both the moisture content (12- 20\%) and rotational speed $(40-120 \mathrm{rpm})(0.8378-2.5133 \mathrm{~m} / \mathrm{sec})$. the most suitable form obtained was as follows:

$\mathrm{C}=2.300(\mathrm{Mc})-0.271(\mathrm{~V})+18.825 \quad \mathrm{R} 2=0.881$

Where:

$\mathrm{C}:$ is the operational cost, LE/ton.

\section{CONCLUSION}

A local corn sheller was evaluated at rotational speeds of (40, 60, 80, 100 and $120 \mathrm{rpm}$ ) and moisture contents of (12, 16 and 20\%) of corn grains. The sheller productivity, shelling efficiency, unshelled grains, grain damage, loose grains at kernel outlet, specific energy consumption and operational costs were determined. The most important results obtained are summarized as follows:

1- By using the local corn sheller, sheller productivity, shelling efficiency, and the percentage of unshelled grains ranged from 0.43 to $1.46 \mathrm{ton} / \mathrm{h}$, from 94.25 to $99.43 \%$, and from 0.57 to $5.75 \%$, respectively.

2- The percentage of grain damage and loose grains at kernel outlet ranged from 0.21 to $2.13 \%$, and 1.57 to $25.15 \%$, respectively.

3- The specific energy consumption and operational cost ranged from 0.74 to $6.87 \mathrm{~kW} . \mathrm{h} /$ ton and from 18.19 to $64.42 \mathrm{LE} / \mathrm{ton}$, respectively.

4- Shelling corn having $12 \%$ moisture content, at rotational speed of 120 rpm gave better results but there was considerable damage as compared to slow speed of shelling operation.

5- When maize cobs with $12 \%$ moisture content were fed to sheller at rotational speed of $120 \mathrm{rpm}$, gave higher productivity (1.46 ton/h) and efficiency of shelling $(99.43 \%)$ but less operational cost $(26.36 \mathrm{LE} / \mathrm{h})$ compared to the other treatments. The cost incurred to shell one ton of maize cobs was 18.05 LE/ton which included the fixed and variable costs at $12 \%$ moisture content and $120 \mathrm{rpm}$ rotational speed. 


\section{REFERENCES}

Al Jalil and M. Chowdury. 1980. Laboratory studies of a low damage corn shelling machine. Trans. Of ASAE, 11(2): 278-283.

Arif, E. M. 2003. Design of simple corn Shellers for farmer house. Misr J. of Agric. Eng., Vol. 81, No. 4.

Awady, M. N. 1978. Engineering of tractors and agricultural machinery, Text book, Fac. Agric., Ain Shams Univ., 5th ed.: 164-167. (In Arabic).

Ayetigbo, M. O. 2001. Design and construction of maize sheller. PGD Thesis, Federal University of Technology, Akure, Nigeria.

Buliaminu, K. 2011. Development of a roll-in oriented machine for maize shelling. Journal of Materials Science and Engineering, B 1: 530-535.

Chilur, R., Sushilendra, V. Palled, M. Veeranouda, R.S. Yaranal, S. Hiregoudar, N. B. Mareppa. 2014. Effect of operational parameters on dehusking cum-shelling efficiency and broken grain percentage of maize dehusker-cum sheller. International J. of Science Research, 3(8): 2277-8179.

$\begin{array}{llll}\text { Food and Agricultural Organisation } & \text { (FAO).2014. }\end{array}$ http://faostat3.fao.org/download/Q/QC/E

Kurt, G. 1997. Engineering formulas. 3rd. Ed. Mc Graw - Hill book Co.

Metwally, K. A. 2010. Study the effect of some operational Factors on hammer mill. MSc Thesis of Department of Agricultural Engineering, Fac. of Agric., Zagazig Univ., Egypt.

Naveenkumar, D. B. and K. S. Rajshekarappa. 2012. Performance evaluation of a power operated maize sheller. Internal. J. agric. Eng., 5(2):172-177. 
Odigboh, E. U. 1997. Machines for crop production. In: Stout BA, editor. Handbook of agricultural engineering-plant production engineering. American Society of Agricultural Engineers.

Wanjala, N. F. 2014. Design of a Modified Hand Operated Maize Sheller. Engineering Design Project Report submitted to the University of Nairobi.

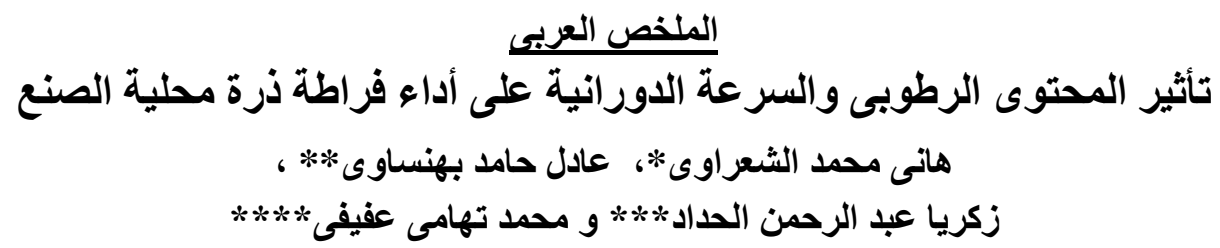

يهدف البحث الى دراسة تأثير الدحتوى الرطوبى للحبوب والسرعة الدورانية للالة على أداء فراطة ذرة محلية الصنع وقد نم ذللك باختبار فراطة ذرة محلية الصنع وذلك بتغيير السرعة الترائ

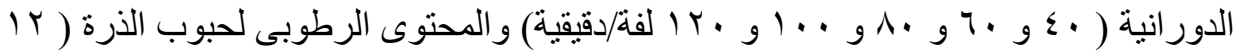

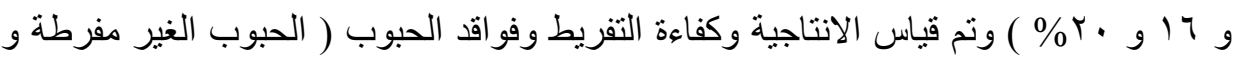
الحبوب المفقودة من مخرج القوالح ) ونسبة الكسر بالحبوب ومنطلبات الطاقة والاستهلاك النوعى للطاقة وتكلفة تشغيل الماكينة لكل معاملة على حدة ونت التم تحليل النتائج المتحصل عليها

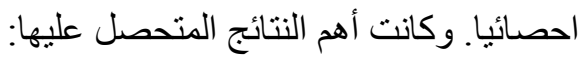

1- من خلال استخدام ماكينة تفريط الذرة المحلية الصنع كانت كفاءة التفريط وكفاءة

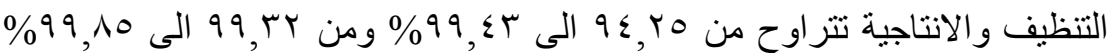

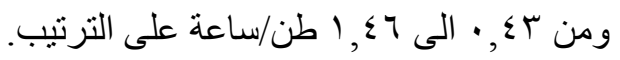
rـ النسبة المئوية للحبوب الغير مفرطة ونسبة الكسر بالحبوب ونسبة الحبوب المفقودة من

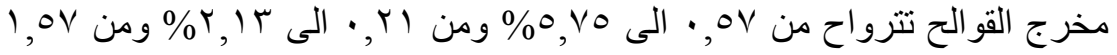

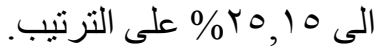

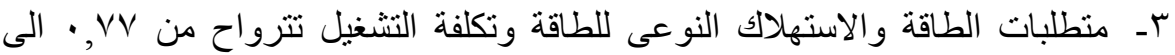

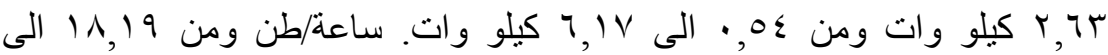

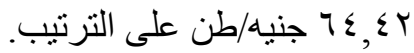

الكلمات الدالة: فر اطة ذرة ، الانتاجية ، كفاءة التفريط ، الاستهلاك النو عى للطاقة .

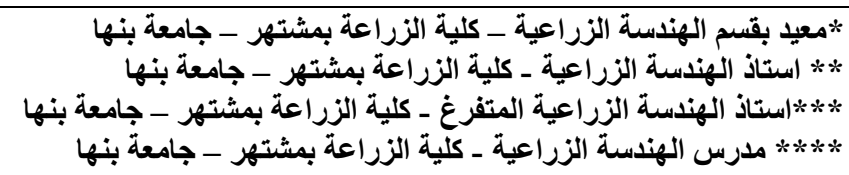


ع - ـ وجد أن عملية التفريط للذرة ذات نسبة رطوبة با \% و وعلى سرعة دور انية لقرص

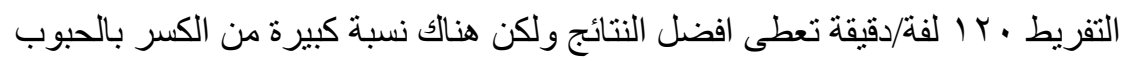
اذا ما قورنت بالسر عات المنخفضة لعملية التفريط.

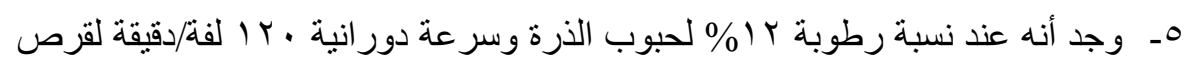

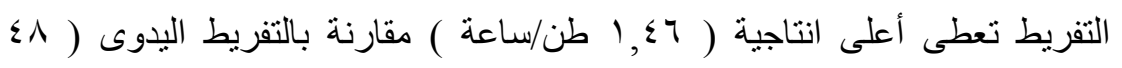

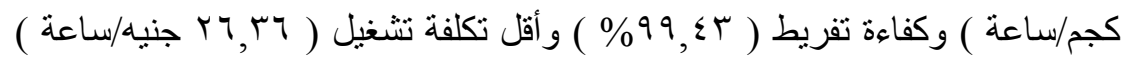

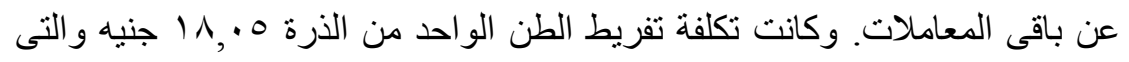
تشمل التكاليف الثابتة والمتغيرة. 